\title{
Food-drug interaction and pharmacokinetic study between fruit extract of Capsicum frutescens $L$. and glimepiride in diabetic rats
}

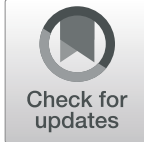

Mettupalayam Annadurai Raja', Prasenjit Mondal ${ }^{2 *}$, Kola Venu ${ }^{3}$, Manish Kumar Thimmaraju ${ }^{4}$ and Poudala Kiran ${ }^{4}$

\begin{abstract}
Background: The present study was designed to explore the food-drug and pharmacokinetic interaction between C.frutescens, a culinary herb on hypoglycemic activity of glimepiride, a sulfonyl urea derivative used in the treatment of type-2 diabetes) in diabetic rats in combination of each as single doses for one day. Further it is also aimed to study the effect of AQEFCF on antidiabetic effect of glimepiride by repeated dose treatment of AQEFCF for 8 days followed by single dose of Glimepiride in diabetic rats and also with repeated dose treatment of both drugs for 8 days in diabetic rats.
\end{abstract}

Methods: Acute toxicity study was conducted as per OECD guidelines 425, as per this study maximum $2000 \mathrm{mg} / \mathrm{kg}$ dose was given to albino mice as observed for mortality of the aqueous extract of C.frutescens. Later in order to know the dose dependent action three doses were selected (1/5th,1/10th and 1/20th) for antidiabetic study. Before treatment with either AQEFCF or Glimepiride fasting ' 0 ' blood samples were collected and serum glucose levels were analysed by GOD-POD method using semi-auto analyser. AQEFCF (100, 200 and $400 \mathrm{mg} / \mathrm{kg}$ p.o) glimepiride 1/ 2TD, TD and 2TD $(0.036,0.072$ and $0.144 \mathrm{mg} / 200 \mathrm{~g}$ p.o) were administered orally alone as well as in combination i.e. AQEFCF as single dose followed by a single dose of glimepiride $30 \mathrm{~min}$ later in Phase I. In II Phase repeated doses of AQEFCF for 8 days followed by a single dose of glimepiride (30 min later) on 8th day. In Phase III both the drugs are administered as single doses for 8 days in the same group of diabetic rats. After the treatment serum glucose levels were determined in all the groups of rats at prefixed time intervals i.e.; 1, 2, 3, 4, 6, 8, 10, 12,16 and $24 \mathrm{~h}$.

Results: Both AQEFCF and glimepiride when administered as single doses produced a dose dependent antidiabetic activity in diabetic rats. The combination of AQEFCF and glimepiride at the different dose levels has shown an better antidiabetic effect. AQEFCF augmented the effect of glimepiride in streptozotocin induced diabetic rats.

Conclusion: It has been concluded that no significant food drug interaction occurred between AQEFCF of $C$. frutescence and glimepiride either single dose or combination of repeated doses. Empirical evidences clears that there is also no pharmacokinetic interaction also observed.

Keywords: Food-drug interaction, C.frutescens fruit, Glimepiride, Streptozotocin, Diabetic rats, Serum glucose

\footnotetext{
* Correspondence: prasenjitmyname@gmail.com

Vaageswari Institute of Pharmaceutical sciences, LMD Colony, Karimnagar

505481 , India

Full list of author information is available at the end of the article
}

\section{Springer Open}

(c) The Author(s). 2020 Open Access This article is licensed under a Creative Commons Attribution 4.0 International License, which permits use, sharing, adaptation, distribution and reproduction in any medium or format, as long as you give appropriate credit to the original author(s) and the source, provide a link to the Creative Commons licence, and indicate if changes were made. The images or other third party material in this article are included in the article's Creative Commons licence, unless indicated otherwise in a credit line to the material. If material is not included in the article's Creative Commons licence and your intended use is not permitted by statutory regulation or exceeds the permitted use, you will need to obtain permission directly from the copyright holder. To view a copy of this licence, visit http://creativecommons.org/licenses/by/4.0/. 


\section{Background}

Ayurvedic herbal preparations often consist of complex mixtures of plant materials practiced in many countries of the Indian subcontinent [1]. Herbal products are being used as a home remedies worldwide in a variety of healthcare settings and are often promoted to the public as being "natural" and completely "safe" alternatives to conventional medicines [2]. Diatery suppliments which contains single or mixture of herbs which are also known as botanicals, can be used for their flavor, scent and therapeutic properties [3]. A food/drug interaction occurs when a food, or one of its components interferes with the way a drug is acts in the body [4]. Food-drug interactions are more challenging (since food consumption is not documented on patient profiles), but often pose equally substantial risk of negative outcome. Interactions between food and drugs can have profound influence on the success of drug treatment and the side effect profiles of many drugs. Foods can interfere in a number of ways with drug action at different stages. The most common effect is of foods interference with drug at absorption level making the drug less effective [5]. In drug absorption process food place a vital role. In some cases the altering absorption mechanism remains unclear, In certain medications indigested food or liquid occasionally causes alteration in absorption [6]. The fruit extract of Capsicum frutescens L has already reported the presence of anti-diabetic activity [7]. Similarly Glimiperide is also a well known antidiabetic drug and which is already reported [8]. Based on the above fact, it came to our mind that, if any diabetic patient who is regularly consuming Glimiperide, what should be the effect of Capsicum frutescens $L$ to the diabetic patient. So the present study was designed to observe the effect of Capsicum frutescens L with Glimepiride. Since no study was available on food drug interaction of capsicum with oral hypoglycemic drugs (Fig. 1), the present study was planned to ivestigate the food-drug interactions and pharmacokinetic study between a widely used dietary food preparations like Capsicum frutescens $\mathrm{L}$, and a synthetic oral antidiabetic drug glimepiride, since both posses hypoglycemic activity.

\section{Materials and methods}

\section{Plant material}

The fruits of the C.frutescens were collected from the Raitu Bazaar, Raichur, India in the month of July and were authenticated and confirmed by the botanist of V.L. College of Pharmacy, Raichur, Karnataka. Then it was dried in shade at room temperature and subjected to size reduction to a fine powder using grinder mixer.

\section{Preparation of aqueous extract}

The fruit powder of C.frutescens was macerated with distilled water (containing $2 \%$ chloroform $(10 \mathrm{ml})$, which acts as preservative) for $24 \mathrm{~h}$ with occasional stirring for every $60 \mathrm{~min}$. Then the resultant was filtered through muslin cloth. The filtrate was dried on a water bath maintained at $45^{\circ} \mathrm{C}$ to get a solid mass. All these extracts were stored in an airtight container in a refrigerator below $10^{\circ} \mathrm{C}$.

\section{Experimental animals}

Wister strain of albino rats of both sex (150-200 g) and either sex of albino mice (16-25g) were collected from the National Centre for Laboratory Animal Science, Bengaluru, India to carry out the experimental study. All the animals were acclimatized for one week using standard animal husbandry conditions, as per CPCSEA guideline. Synthetic standard diet food (From Pranava Agro Industries ltd, Sangli, India) was supplied to all animals. The study protocol was approved by Institutional animal ethical committee (IAEC) with a registration no. 557/08/c/ CPCSEA.

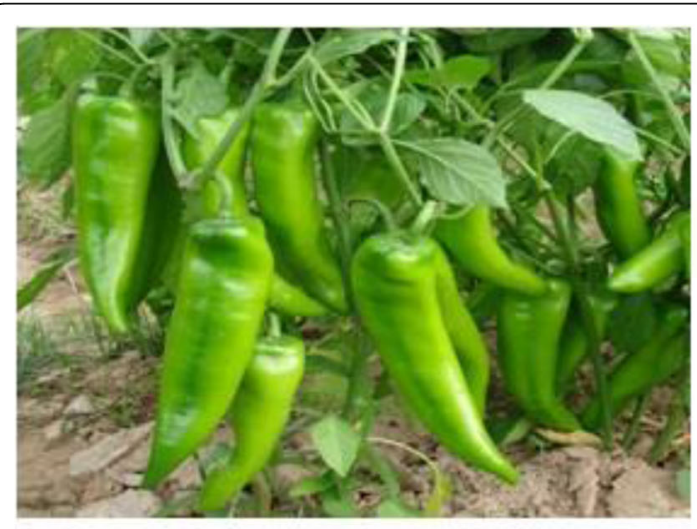

a) Fruit of Capsicum frutescens<smiles>CCC1=C(C)CN(C(=O)NCCc2ccc(S(N)(=O)=O)cc2)C1=O</smiles>

b) Chemical structure of glimepiride

Fig. 1 Image of C.frutescens and chemical structure of glimpiride 


\section{Chemicals and drugs}

Glimepiride was obtained from the Dr. Reddys Lab, Hyderabad, India. Glucose kit from Erba Mannheim, Mumbai, India, Trisodium citrate and Citric acid monohydrate form S.d.fine chemicals limited, Bengaluru, India.

\section{Determination of acute toxicity $\left(\mathrm{LD}_{50}\right)$}

The oral acute toxicity study [9] of the extract was determined by using albino mice of either sex (16-25 g), maintained under standard husbandry conditions. The animals were fasted for $3 \mathrm{~h}$ prior to the experiment. Animals were administered with single dose of extract of C.frutescens and observed for its mortality up to $48 \mathrm{~h}$ study period (short term toxicity). Based on the shortterm toxicity profile, the next dose was determined as per OECD Guidelines No 425. From the $\mathrm{LD}_{50}$ dose $1 /$ 20th, $1 / 10$ th and $1 / 5^{\text {th }}$ doses were selected and considered as low, medium and high dose respectively and used in the entire study.

\section{Induction of diabetes}

Rats of either sex weighing between 175 and $200 \mathrm{~g}$ were selected and fasted for $18 \mathrm{hs}$ prior to experiment and water supplied ad-libitum. The animals were kept in colony cages at ambient temperature of $28 \pm 2{ }^{\circ} \mathrm{C}$ and relative humidity 45 to $55 \%$ with a $12 \mathrm{~h} \mathrm{light/} \mathrm{dark} \mathrm{cycle.}$ The rats were administered with $45 \mathrm{mg} / \mathrm{Kg}$ of Streptozotocin intraperitoneally [10].

\section{Dose selection of glimepiride}

The human dose $(4 \mathrm{mg} / \mathrm{Kg}$, p.o.) of Glimepiride was extrapolated to rat dose based on body surface area and weight. The dose effect relationship is established using $1 / 2$ TD, TD and 2 TD (i.e; TD is therapeutic dose) the human dose $(4 \mathrm{mg} / \mathrm{Kg}$, p.o.) of Glimepiride extended to rat as $1 / 2$ TD ( $0.036 \mathrm{mg} / 200 \mathrm{~g}$, p.o.), TD $(0.072 \mathrm{mg} / 200 \mathrm{~g}$, p.o.) and $2 \mathrm{TD}(0.144 \mathrm{mg} / 200$ g, p.o.) [11]

\section{Method for oral administration of drug}

An 18 -gauge needle was suitably covered with flexible polythene tubing, where the edge was made blunt; the needle was fixed to $1 \mathrm{ml}$ tuberculin syringe. The rat was held firmly in left hand, the tubing was moistened with glycerine and inserted right into the esophagus and gently pressing plunger for drug administration, and this was followed by $0.2 \mathrm{ml}$ of distilled water to ensure administration of correct dose of the drug.

\section{Method for collection of blood sample}

The rat was placed into the rat holder, such that the tail was pulled out and was deplitated for collection of blood sample [12]. Tail vein was dilated by focusing a low voltage electric lamp. The tip of the tail was thin sliced
$(0.05 \mathrm{~mm})$ using a sharp scissors. The blood drops were collected though the walls of $0.5 \mathrm{ml}$ of centrifuge tube (to avoid haemolysis of the blood sample). The tail was gently pressed with fingers to enhance the blood flow and allowed to clot in centrifuge tube. Later dry cotton was applied for few minutes to stop the blood flow and the tail was sterilized by spirit.

\section{Method of collection of serum}

The serum was obtained by centrifuging the blood samples for $20 \mathrm{~min}$ (3000 rpm), supernatant fluid was decanted into the clean dry test tube.

\section{Experimental study in diabetic rats}

The groups of Wistar albino rats (35) of either sex weighing 160-180 g were selected for the study and kept in colony cages at ambient temperature of $28 \pm 2{ }^{\circ} \mathrm{C}$ and relative humidity of 45 to $55 \%$ with a $12 \mathrm{~h} \mathrm{light/dark} \mathrm{cycle.} \mathrm{The} \mathrm{an-}$ imals were fasted for $18 \mathrm{~h}$ before commencing the experiment with water ad libitum. The fasting was continued till completion of the experiment. The ' 0 ' $\mathrm{h}$ blood samples were collected for estimation of fasting serum glucose.

\section{In stage 1: anti diabetic activity one day study}

The study is planned to assess the hypoglycemic activity of single doses of AQEFCF and glimepiride in diabetic rats. Group 1 animals are administered wih $0.1 \mathrm{~N} \mathrm{NaOH}$ vehicle, Groups 2, 3 and 4 were administered with 100, 200 and $400 \mathrm{mg} / \mathrm{Kg}$ AQEFCF and Group 5, 6 and 7 are administered with $1 / 2 \mathrm{TD}$, TD and 2 TD glimepiride.

\section{In stage 2: anti diabetic activity one week study}

The present study is planned to assess the hypoglycemic activity of repeated doses of AQEFCF and glimepiride in diabetic rats. Group 8 was administered with $0.1 \mathrm{~N} \mathrm{NaOH}$ vehicle Groups 9, 10 and 11 are administered with 100, 200 and $400 \mathrm{mg} / \mathrm{Kg}$ AQEFCF and Groups 12, 13 and 14 are administered with $1 / 2 \mathrm{TD}$, TD and $2 \mathrm{TD}$ glimepiride.

\section{In stage 3: food-drug interaction one day study}

The study was planned to evaluate the influence of single dose of AQEFCF on hypoglycemic activity of single dose of glimepiride in diabetic rats. In this, Group 15 was given AQEFCF $100 \mathrm{mg} / \mathrm{Kg}$ + glimepiride $1 / 2 \mathrm{TD}$, Group 16 received AQEFCF $200 \mathrm{mg} / \mathrm{Kg}+$ glimepiride $1 / 2$ TD Group 17 received AQEFCF $400 \mathrm{mg} / \mathrm{Kg}+$ glimepiride $1 / 2$ TD Group 18 received AQEFCF $100 \mathrm{mg} / \mathrm{Kg}+$ glimepiride TD Group 19 received AQEFCF $200 \mathrm{mg} / \mathrm{Kg}+$ glimepiride TD Group 20 received AQEFCF $400 \mathrm{mg} /$ $\mathrm{Kg}+$ glimepiride TD Group 21 received AQEFCF 100 $\mathrm{mg} / \mathrm{Kg}+$ glimepiride $2 \mathrm{TD}$, Group 22 received AQEFCF $200 \mathrm{mg} / \mathrm{Kg}$ + glimepiride $2 \mathrm{TD}$ and Group 23 received AQEFCF $400 \mathrm{mg} / \mathrm{Kg}+$ glimepiride $2 \mathrm{TD}$. 


\section{In stage 4: food-drug interaction 8 days study}

The interaction study was planned to investigate the effect of repeated doses of AQEFCF for 8 days followed by glimepiride on 8th day in diabetic rats. In this, Group 24 received AQEFCF $100 \mathrm{mg} / \mathrm{Kg}$ + glimepiride $1 / 2$ TD Group 25 received AQEFCF $200 \mathrm{mg} / \mathrm{Kg}$ + glimepiride $1 / 2$ TD Group 26 received AQEFCF $400 \mathrm{mg} / \mathrm{Kg}$ + glimepiride $1 / 2$ TD Group 27 received AQEFCF $100 \mathrm{mg} / \mathrm{Kg}+$ glimepiride TD Group 28 received AQEFCF $200 \mathrm{mg} / \mathrm{Kg}$ + glimepiride TD Group 29 received AQEFCF $400 \mathrm{mg} / \mathrm{Kg}+$ glimepiride TD Group 30 received AQEFCF $100 \mathrm{mg} /$ $\mathrm{Kg}+$ glimepiride 2TD Group 31 received AQEFCF 200 $\mathrm{mg} / \mathrm{Kg}+$ glimepiride $2 \mathrm{TD}$ and Group 32 received AQEF CF $400 \mathrm{mg} / \mathrm{Kg}+$ glimepiride 2TD. Animals are administered with AQEFCF for one week. Later, the rats are fasted for $18 \mathrm{~h}$. On the 8 th day, after collecting the fasting blood samples from tail vein AQEFCF is given orally to all the rats and $30 \mathrm{~min}$ later, glimepiride is administered orally. Serum glucose levels are estimated.

\section{In stage 5: food-drug interaction $\mathbf{8}$ days study (selective doses from stage 4)}

The study was planned to evaluate food-drug interaction between repeated doses of both AQEFCF and glimepiride for 8 days in diabetic rats. In this Group 33 received AQEFCF $400 \mathrm{mg} / \mathrm{Kg}$ + glimepiride $1 / 2$ TD Group 34 received AQEFCF $400 \mathrm{mg} / \mathrm{Kg}$ + glimepiride TD Group 35 received AQEFCF $400 \mathrm{mg} / \mathrm{Kg}$ + glimepiride 2TD. Animals are administered with AQEFCF and glimepiride with an interval of $30 \mathrm{~min}$ for one week. Later, the rats are fasted for $18 \mathrm{~h}$. On the 8th day, after collecting the fasting blood samples from tail vein AQEFCF is given orally to all the rats and $30 \mathrm{~min}$ later, glimepiride is administered orally. Serum glucose levels are estimated.

\section{Percentage reduction in serum glucose at time " $t$ " $t=A$ - $\mathrm{B} / \mathrm{A} \times \mathbf{1 0 0}$ \\ Where:}

A is serum glucose concentration at time " 0 " and

$B$ is serum glucose concentration at time " $t$ "

\section{Chemiluminescence Immunoassay Method for Insulin}

To carry out the assay of control and test in duplicate, all the micro plate wells were formatted. Replace any unused micro well strips back into the aluminum bag, seal and store at $2-8{ }^{\circ} \mathrm{C}$.Pipette $0.05 \mathrm{ml}(50 \mu \mathrm{l})$ of the appropriate calibrators, controls and samples into the assigned wells. Add $0.1 \mathrm{ml}$ of the insulin tracer reagent to each well. For the proper mixing micro plate swirl gently for $20-30 \mathrm{~s}$. Plastic wrap is used to cover the plates and incubate at room temperature for $60 \mathrm{~min}$. Read the Relative light units using a 96 well micro plate laminator for $0.2-1.0 \mathrm{~s}$ per well. The results should be read within $30 \mathrm{~min}$ of adding the stop solution. The microplate contents were discarded by aspiration or decantation. For decanting tap and blot the microplates with the use of dry adsorbent paper. Wash buffer $(350 \mu \mathrm{L})$ was used to decant or aspirate. Repeat the procedure for five washed. Manual or automatic plate washer can also be used. Add working signal reagent $(0.1 \mathrm{~mL})$ to all the wells. In the same order the reagents were added to minimize reaction time difference between the wells and incubate in the dark for $5 \mathrm{~min}$ at room temperature [13].

\section{Statistical analysis}

The results were expressed as the mean \pm SEM and were analyzed by one-way ANOVA followed by Dunnett's multiple comparison "t" test. Data was computed for statistical analysis by using Graph Pad PRISM 5 Software.

\section{Pharmacokinetic study}

In this study 24 Wister albino rats of either sex (160$180 \mathrm{~g}$ ) were randomly selected and divided in to four groups containing six rats in each group. Animas were kept fasting for $18 \mathrm{~h}$ except water. For this study the single dose if glimepiride 1TD $(0.72 \mathrm{mg} / 200 \mathrm{mg})$ and single dose of C. frutescens $(200 \mathrm{mg} / \mathrm{kg}$ ) was administered. The drugs were administered through the oral route using oral feeding needle (size --) to various groups in following order.

\section{Group I: Control}

Group II: Glimepiride $(0.072 \mathrm{mg} / 200 \mathrm{~g})$

Group III: 200 mg/kg C.frutescens

Group IV: $200 \mathrm{mg} / \mathrm{kg}$ C.frutescens for 14th day. On 15 th day C. frutescens $200 \mathrm{mg} / \mathrm{kg}$, followed by glimepiride $0.072 \mathrm{mg} / 200 \mathrm{~g}$

The blood samples $(0.6 \mathrm{~mL})$ were collected through the retro-orbital route, with light anaesthesia using $0.2 \%$ Phenobarbital sodium in i.p route. The blood samples were collected at the time internal of $0,0.5,1,1.5,2,2.5$, $4,6,8,10,12$ and $24 \mathrm{~h}$ of administered dose. The collected blood samples were transferred to polypropylene tube (K2 EDTA, J. K diagnostic, Rajkot). The plasma was separated immediately and processed to obtain the plasma samples by protein precipitation method, that has been described in the section of "plasma extraction method." The plasma samples were then injected in to the chromatographic system. The obtain data were used to construct a plasma concentration vs time profile. The pharmacokinetic parameters were obtained using linear $\log$ trapezoidal rule method.

\section{Plasma extraction method}

The blood samples that has been withdrawn were processed by protein precipitation technique [14]. Accurately $0.2 \mathrm{~mL}$ of blood sample were transferred in to a micro centrifuge tube and spiked with $20 \mu \mathrm{L}$ of $20 \mathrm{ng} / \mathrm{mL}$ of aqueous internal 
standard (glipizide) solution. $0.5 \mathrm{~mL}$ of acetonitrile was added to the tube. The samples were vortexed for $30 \mathrm{~s}$ to ensure complete mixing. Separation of two phase were performed by centrifugation at 7000 rotation per minute for the time period of $5 \mathrm{~min}$. The supernatant was transferred in to other glass tube followed by complete evaporation under a stream of nitrogen at $40^{\circ} \mathrm{C}$. The obtained dry residue was reconstituted with $120 \mu \mathrm{L}$ mobile phase. Finally $20 \mu \mathrm{L}$ of above sample was injected in to the chromatographic system.

\section{Optimised analytical condition}

Plasma glimepiride was determined using a validated LCMS/MS method [15]. The separation was achieved on Zorbax C-18 stable band $(4.6 \mathrm{~mm}$ id $\times 50 \mathrm{~mm})$ column. The tendem mass spectroscopy was performed with API 3000 triple quadrupole mass spectrophotometer (ABSCIEX, Foster city, Ontario, Canada.). The mobile phase consist of $80 \%$ acetonitrile and $20 \%$ deionised water ( $\mathrm{pH} 3.5$ adjusted with acetic acid) used after diagnosis, with a flow rate of $200 \mu \mathrm{L} / \mathrm{min}$ and $2.5 \mathrm{~min}$ run time. Glimepride and internal standard (glipizide) were detected by MRM scan with positive ion mode. The tuning parameters consist of $20 \mathrm{v}$ cone voltage, extractor at $2 \mathrm{v}$, source temperature at $120^{\circ} \mathrm{C}$, collision cell entrance potential at $-1.0 \mathrm{~V}$, with a collision energy $12 \mathrm{eV}$ and dwell time of $0.5 \mathrm{~s}$.

\section{Results}

\section{Acute oral toxicity study}

When the aqueous extract of C.frutescens (AQEFCF) was administered orally to different groups of mice at different dose levels, it was found that even up to the dose level of $2000 \mathrm{mg} / \mathrm{Kg}$ body weight, the extract showed no effect either on behavioral symptoms or mortality during the observation period of $48 \mathrm{~h}$ (short term toxicity) and no mortality observed up to 14 days of experimental study (long term toxicity).

\section{Anti diabetic activity of AQEFCF and glimepiride}

$0.1 \mathrm{~N} \mathrm{NaOH}$ used as vehicle in control has not shown any reduction in the serum glucose levels in both single and in repeated treatment studies

\section{Effect of single dose treatment of AQEFCF on serum glucose levels in diabetic rats}

AQEFCF with three different doses like 100, 200, 400 $\mathrm{mg} / \mathrm{Kg}$ p.o. has produced a dose dependent reduction in serum glucose levels in diabetic rats. The maximum serum glucose reduction observed at 6 th $\mathrm{h}$ of each individual dose recorded as $15.32 \%, 19.63 \%$ and $22.16 \%$ respectively was shown in Table 1.
Effect of single dose treatment of glimepiride on serum glucose levels in diabetic rats

Glimepiride with three different doses like $1 / 2 \mathrm{TD}$, TD, and 2TD has produced a dose dependent reduction in serum glucose levels in diabetic rats. The maximum serum glucose reduction was observed at 6 th $\mathrm{h}$ of each individual dose recorded as $33.10 \%, 39.79 \%$ and $48.67 \%$ respectively was shown in Table 2 .

\section{Effect of repeated dose treatment of AQEFCF on serum glucose levels in diabetic rats}

AQEFCF with three different doses like 100, 200, 400 $\mathrm{mg} / \mathrm{Kg}$ p.o. has produced a dose dependent reduction in serum glucose levels in diabetic rats. The maximum serum glucose reduction observed with these three doses is $17.19 \%, 24.93$ and 30.76 all at 6 th $\mathrm{h}$ respectively.

\section{Effect of repeated dose treatment of glimepiride on serum glucose levels in diabetic rats}

Glimepiride with three different doses like $1 \frac{1}{2}$ TD, TD, 2 TD p.o. has produced a dose dependent reduction in serum glucose levels in diabetic rats. The maximum serum glucose reduction observed with these three doses is $40.39,48.61$, $53.76 \%$ respectively and all noted at 6 th $\mathrm{h}$. When compared with vehicle control, AQEFCF (100, 200, $400 \mathrm{mg} / \mathrm{Kg}$ p.o.) single and repeated treatment groups has shown a dose dependent and significant reduction in serum glucose levels throughout the experimental study. When compared with vehicle control glimepiride (1/2TD, TD, and 2 TD p.o.) single and repeated treatment groups has shown a dose dependent and significant reduction in serum glucose levels throughout the experimental study. All the treated groups i.e. AQEFCF 100, 200, $400 \mathrm{mg} / \mathrm{Kg}$ p.o. and glimepiride $1 / 2 \mathrm{TD}, \mathrm{TD}, 2 \mathrm{TD}$ p.o. has shown a maximum reduction of $15.32,19.63,22.16 \%$ and $33.10,43.85,50.55 \%$ after single doses treatment and 17.19, 24.93, 30.76\% and 40.39,48.61, $53.76 \%$ in repeated doses treatment respectively at 6 th $\mathrm{h}$.

\section{Influence of single dose treatment of AQEFCF on antidiabetic activity of glimepiride (single dose) in diabetic rats (one day interaction study)} AQEFCF $100,200,400 \mathrm{mg} / \mathrm{Kg}$, p.o. treatment followed by glimepiride $1 / 2 \mathrm{TD}(0.036 \mathrm{mg} / 200 \mathrm{~g}$, p.o $)$ in each group has produced a significant reduction in serum glucose levels in diabetic rats. The maximum serum glucose reduction observed with these three doses is $33.59 \%, 34.04$ and $35.22 \%$ respectively at 6 th $\mathrm{h}$. AQEFCF $100,200,400$ $\mathrm{mg} / \mathrm{Kg}$, p.o. treatment followed by glimepiride TD (0. $072 \mathrm{mg} / 200 \mathrm{~g}$, p.o) has produced a significant reduction in serum glucose levels in diabetic rats. The maximum serum glucose reduction observed with these three doses is $40.21 \%, 41.82 \%$ and $42.12 \%$ respectively at 6 th $\mathrm{h}$. AQEFCF 100, 200, $400 \mathrm{mg} / \mathrm{Kg}$, p.o. treatment followed by glimepiride $2 \mathrm{TD}(0.144 \mathrm{mg} / 200 \mathrm{~g}$, p.o $)$ has produced 
Table 1 Effect of single dose of C. frutescens on serum glucose level and \% reduction in diabetic rats

\begin{tabular}{|c|c|c|c|c|c|c|}
\hline \multirow[t]{2}{*}{ Time (hr) } & \multicolumn{3}{|l|}{ SERUM GLUCOSE (mg/dL) } & \multicolumn{3}{|l|}{$\%$ REDUCTION } \\
\hline & C. frutescens (100 mg/kg) & C. frutescens (200 mg/kg) & C. frutescens ( 400 mg/kg) & C. frutescens (100 mg/kg) & C. frutescens (200 mg/kg) & $\begin{array}{l}\text { C. frutescens } \\
(400 \mathrm{mg} / \mathrm{kg})\end{array}$ \\
\hline 0 & $309.17 \pm 2.08$ & $311.62 \pm 2.09$ & $307.38 \pm 1.56$ & - & - & - \\
\hline 1 & $296.72 \pm 3.59$ & $296.20 \pm 1.91$ & $288.20 \pm 1.85$ & $4.02 \pm 1.08^{* *}$ & $4.94 \pm 0.77^{* * *}$ & $6.24 \pm 0.64^{* * *}$ \\
\hline 2 & $286.95 \pm 3.15$ & $285.38 \pm 1.57$ & $281.23 \pm 1.17$ & $7.18 \pm 0.99^{* * *}$ & $8.41 \pm 0.79^{* * *}$ & $8.50 \pm 0.12^{* *}$ \\
\hline 3 & $277.33 \pm 3.00$ & $272.32 \pm 2.83$ & $266.33 \pm 1.24$ & $10.28 \pm 1.15^{* * *}$ & $12.60 \pm 1.11^{* * *}$ & $13.35 \pm 0.61^{* * *}$ \\
\hline 4 & $269.80 \pm 2.95$ & $259.18 \pm 3.05$ & $254.53 \pm 2.72$ & $12.71 \pm 1.21^{* * *}$ & $16.80 \pm 1.32^{* * *}$ & $17.17 \pm 1.00^{* * *}$ \\
\hline 6 & $261.72 \pm 2.79$ & $250.35 \pm 2.91$ & $239.25 \pm 5.00$ & $15.32 \pm 1.15^{* * *}$ & $19.63 \pm 1.23^{* * *}$ & $22.16 \pm 1.65^{* * *}$ \\
\hline 8 & $265.40 \pm 2.75$ & $258.77 \pm 3.01$ & $250.02 \pm 4.16$ & $14.14 \pm 0.96^{* * *}$ & $16.93 \pm 1.31^{* * *}$ & $18.67 \pm 1.19^{* * *}$ \\
\hline 10 & $272.43 \pm 2.74$ & $267.42 \pm 3.44$ & $262.35 \pm 2.63$ & $11.86 \pm 1.01^{* * *}$ & $14.47 \pm 1.48^{* * *}$ & $14.65 \pm 0.82^{* * *}$ \\
\hline 12 & $285.72 \pm 1.90$ & $275.80 \pm 3.23$ & $270.42 \pm 2.00$ & $7.57 \pm 0.69^{* * *}$ & $11.47 \pm 1.44^{* * *}$ & $12.02 \pm 0.50^{* * *}$ \\
\hline 16 & $293.28 \pm 1.55$ & $286.47 \pm 1.60$ & $280.15 \pm 2.61$ & $5.13 \pm 0.57^{* * *}$ & $8.06 \pm 0.49^{* * *}$ & $8.83 \pm 1.20^{* *}$ \\
\hline 24 & $301.84 \pm 2.22$ & $298.70 \pm 2.59$ & $292.23 \pm 1.76$ & $2.37 \pm 0.40^{*}$ & $4.14 \pm 0.54^{* * *}$ & $4.91 \pm 0.75^{*}$ \\
\hline
\end{tabular}

$n=6$, ns- non significant, significant at ${ }^{*} P<0.05,{ }^{*} P<0.01,{ }^{* *} P<0.001$ when compared to control group

a significant reduction in serum glucose levels in diabetic rats. The maximum serum glucose reduction observed with these three doses is $51.47 \%, 51.95 \%$ and $52.95 \%$ respectively at 6th h shown in Fig. 2 and Table 2.

\section{Influence of repeated dose treatment of AQEFCF on antidiabetic activity of glimepiride (single dose) in diabetic rats (8 days study)}

AQEFCF $100,200,400 \mathrm{mg} / \mathrm{Kg}$, p.o. repeated dose treatment followed by glimepiride $1 / 2$ TD $(0.036 \mathrm{mg} / 200 \mathrm{~g}$, p.o $)$ has produced a significant reduction in serum glucose levels in diabetic rats. The maximum serum glucose reduction observed with these three doses is $35.12 \%, 36.07 \%$ and $37.35 \%$ at respectively 6 th $\mathrm{h}$. AQEFCF $100,200,400 \mathrm{mg} /$ $\mathrm{Kg}$, p.o. repeated dose treatment followed by glimepiride TD $(0.072 \mathrm{mg} / 200 \mathrm{~g}$, p.o) has produced a significant reduction in serum glucose levels in diabetic rats. The maximum serum glucose reduction observed with these three doses is $40.40 \%, 43.64 \%$ and $46.44 \%$ respectively at 6th h. AQEFCF 100, 200, $400 \mathrm{mg} / \mathrm{Kg}$, p.o. repeated dose treatment followed by glimepiride 2 TD $(0.144 \mathrm{mg} / 200 \mathrm{~g}$, p.o) has produced a significant reduction in serum glucose levels in diabetic rats. The maximum serum glucose reduction observed with these three doses is $51.62 \%, 52.51 \%$ and $53.27 \%$ respectively at 6 th $\mathrm{h}$ shown in Fig. 3 and Table 3.

\section{Influence of repeated dose treatment of AQEFCF on antidiabetic activity of glimepiride (repeated dose treatment) in diabetic rats (8 days study)}

AQEFCF $400 \mathrm{mg} / \mathrm{Kg}$ repeated dose treatment along with repeated doses of $1 / 2 \mathrm{TD}$, TD and $2 \mathrm{TD}$ respectively has produced a significant reduction in serum glucose levels. The maximum reduction observed with the above treatment is recorded as $43.91 \%, 49.09$ and $57.60 \%$ all at 6 th $\mathrm{h}$ respectively. The results are shown in Table 4 .

Table 2 Antidiabetic activity of Glimepiride (GLIM) in diabetic rats

\begin{tabular}{|c|c|c|c|c|c|c|}
\hline \multirow{2}{*}{$\begin{array}{l}\text { Time } \\
\text { (hr) }\end{array}$} & \multicolumn{3}{|c|}{ SERUM GLUCOSE (mg/dL) } & \multicolumn{3}{|l|}{$\%$ REDUCTION } \\
\hline & $1 / 2$ TD GLIM & 1TD GLIM & 2 TD GLIM & $1 / 2$ TD GLIM & 1TD GLIM & 2 TD GLIM \\
\hline 0 & $307.47 \pm 2.89$ & $304.98 \pm 6.80$ & $306.15 \pm 5.12$ & - & - & - \\
\hline 1 & $291.43 \pm 4.13$ & $287.53 \pm 6.70$ & $270.89 \pm 3.23$ & $5.18 \pm 1.57^{* * *}$ & $5.69 \pm 1.23^{* * *}$ & $11.31 \pm 2.48^{* * *}$ \\
\hline 2 & $266.73 \pm 3.51$ & $261.10 \pm 6.42$ & $250.87 \pm 5.80$ & $13.24 \pm 0.92^{* * *}$ & $14.37 \pm 1.26^{* * *}$ & $18.06 \pm 1.30^{* * *}$ \\
\hline 3 & $241.17 \pm 4.12$ & $234.15 \pm 3.69$ & $223.65 \pm 5.50$ & $21.52 \pm 1.61^{* * *}$ & $23.14 \pm 1.10^{* * *}$ & $26.90 \pm 1.76^{* * *}$ \\
\hline 4 & $224.82 \pm 2.94$ & $200.07 \pm 5.61$ & $188.58 \pm 6.10$ & $26.87 \pm 0.79^{* * *}$ & $34.37 \pm 1.14^{* * *}$ & $38.43 \pm 1.48^{* * *}$ \\
\hline 6 & $205.67 \pm 1.54$ & $183.53 \pm 3.91$ & $157.18 \pm 4.71$ & $33.10 \pm 0.45^{* * *}$ & $39.79 \pm 0.76^{* * *}$ & $48.67 \pm 1.20^{* * *}$ \\
\hline 8 & $222.82 \pm 5.28$ & $189.47 \pm 3.21$ & $181.50 \pm 3.76$ & $27.55 \pm 1.36^{* * *}$ & $37.75 \pm 1.51^{* * *}$ & $40.66 \pm 1.33^{* * *}$ \\
\hline 10 & $229.10 \pm 4.15$ & $206.02 \pm 5.50$ & $201.92 \pm 4.51$ & $25.50 \pm 0.97^{* * *}$ & $32.36 \pm 1.82^{* * *}$ & $34.03 \pm 1.11^{* * *}$ \\
\hline 12 & $252.68 \pm 4.37$ & $235.18 \pm 6.49$ & $224.60 \pm 4.47$ & $17.80 \pm 1.35^{* * *}$ & $22.86 \pm 1.53^{* * *}$ & $26.57 \pm 1.58^{* * *}$ \\
\hline 16 & $269.00 \pm 3.21$ & $258.45 \pm 6.56$ & $241.93 \pm 1.44$ & $12.51 \pm 0.72^{* * *}$ & $15.26 \pm 1.08^{* * *}$ & $20.86 \pm 1.43^{* * *}$ \\
\hline 24 & $284.13 \pm 4.78$ & $274.15 \pm 5.75$ & $261.98 \pm 7.00$ & $7.60 \pm 1.12^{* * *}$ & $10.04 \pm 1.47^{* * *}$ & $14.46 \pm 1.41^{* * *}$ \\
\hline
\end{tabular}

$\mathrm{n}=6$, ns- non significant, significant at ${ }^{*} P<0.05,{ }^{*} P<0.01,{ }^{* * *} P<0.001$ when compared to control group 


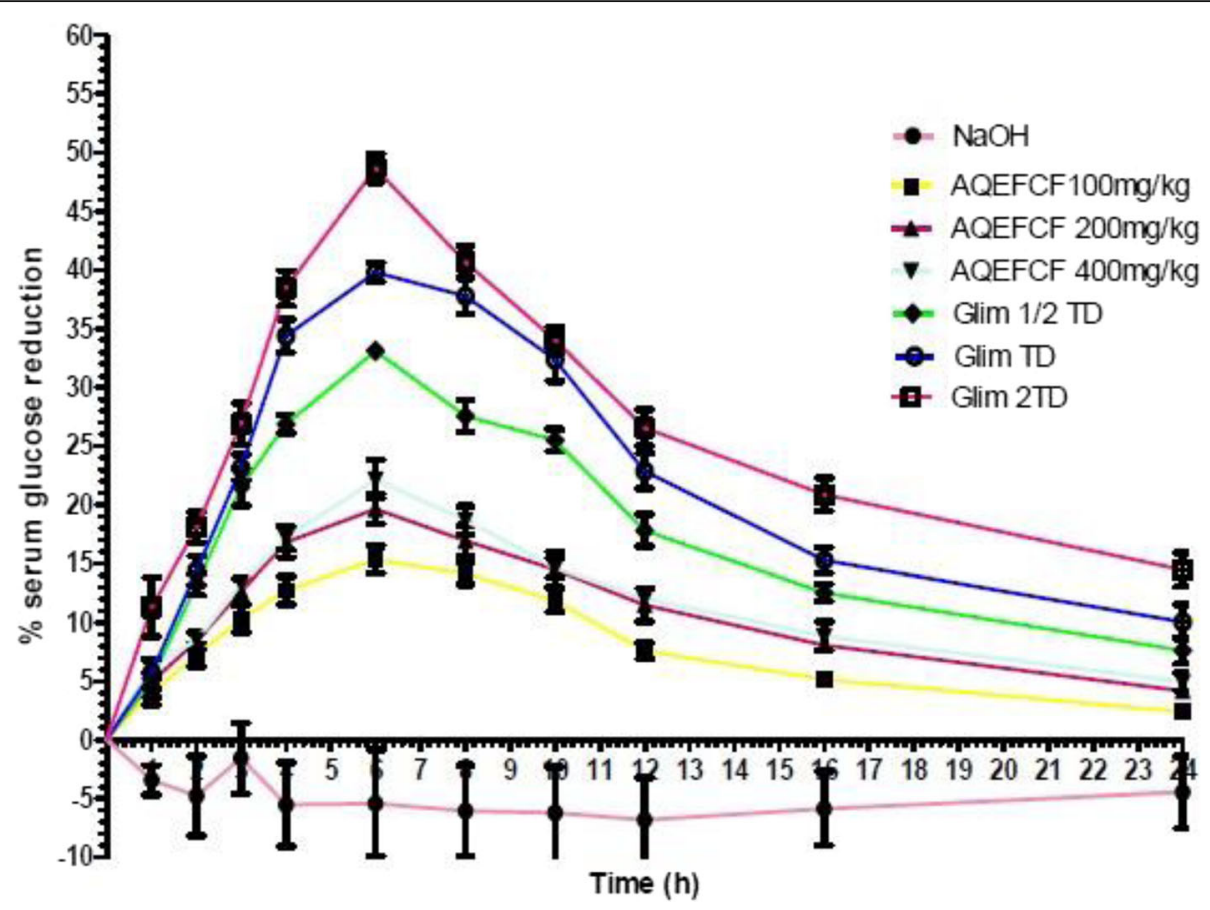

Fig. 2 Effect of single dose of C.frutescens and glimepiride on serum glucose level in diabetic rats

Influence of single dose treatment of AQEFCF on antidiabetic activity of glimepiride (single dose) in diabetic rats (one day interaction study)

When compared with single dose of glimepiride $1 / 2$ TD treated group AQEFCF 100, 200, $400 \mathrm{mg} / \mathrm{Kg}$, p.o. treatment followed by glimepiride $1 / 2$ TD $(0.036 \mathrm{mg} / 200 \mathrm{~g}$, p.o) in respective groups has shown a significant reduction in blood glucose levels at $3,8,10,12,16$ and $24 \mathrm{~h}$ with $100 \mathrm{mg}, 3,4,6$ and $12 \mathrm{~h}$ with $200 \mathrm{mg}$ and 3, 6 and $12 \mathrm{~h}$ with $400 \mathrm{mg}$.

AQEFCF $100,200,400 \mathrm{mg} / \mathrm{Kg}$, p.o. treatment followed by glimepiride TD $(0.072 \mathrm{mg} / 200 \mathrm{~g}, \mathrm{p} . \mathrm{o})$ in respective groups has shown a significant reduction in blood glucose levels at $2,4,6,8,10,12,16$ and $24 \mathrm{~h}$ except $24 \mathrm{~h}$

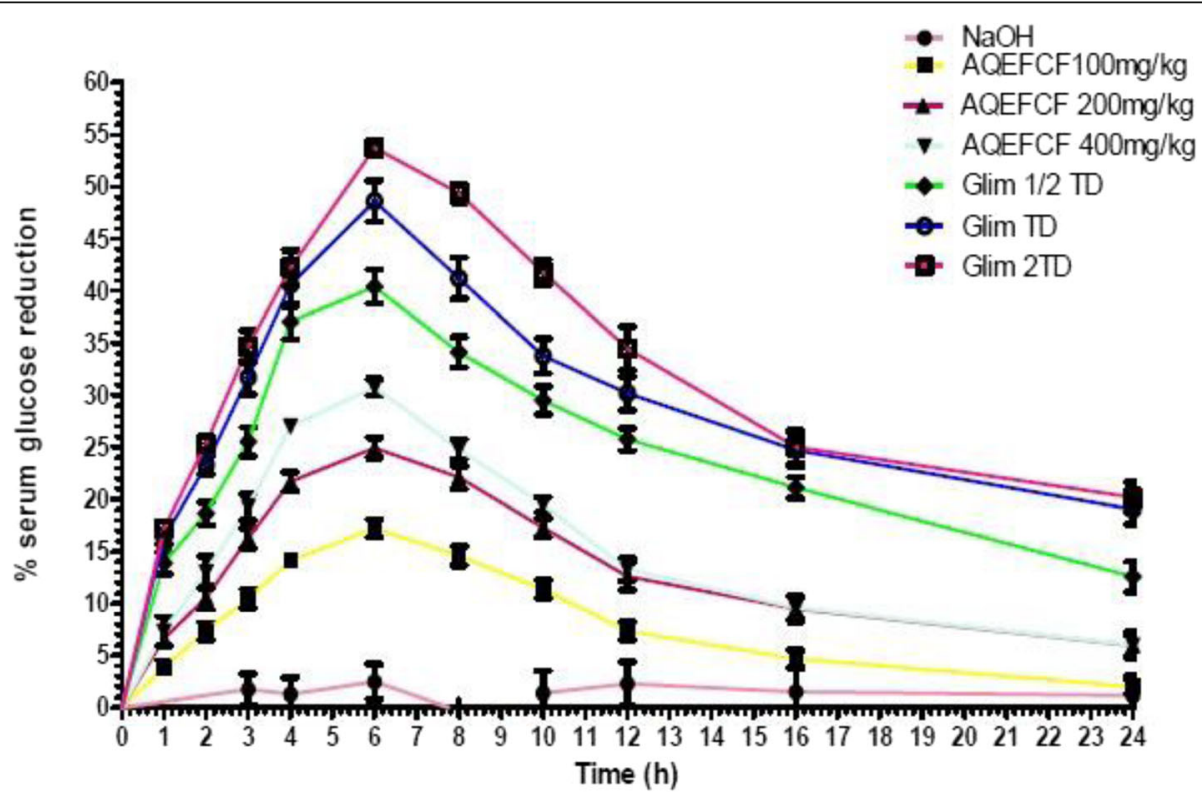

Fig. 3 Effect of repeated dose of C.frutescens and glimepiride on serum glucose level in diabetic rats 
in $100 \mathrm{mg} / \mathrm{Kg}$ treated group. AQEFCF 100, 200, $400 \mathrm{mg} /$ $\mathrm{Kg}$, p.o. treatment followed by glimepiride $2 \mathrm{TD}(0.144$ $\mathrm{mg} / 200 \mathrm{~g}, \mathrm{p} . \mathrm{o})$ in respective groups has shown a significant reduction in blood glucose levels at all time intervals of the experimental study.

When compared with single dose of glimepiride TD treated group AQEFCF $100,200,400 \mathrm{mg} / \mathrm{Kg}$, p.o. treatment followed by glimepiride $1 / 2 \mathrm{TD}(0.036 \mathrm{mg} / 200 \mathrm{~g}, \mathrm{p} . \mathrm{o})$ in respective groups has shown a significant reduction in blood glucose levels at 4, 6, 8, $10 \mathrm{~h}$ except $24 \mathrm{~h}$ in $400 \mathrm{mg} /$ Kg treated group (Table No. 29, 30, 31).AQEFCF 100, 200, $400 \mathrm{mg} / \mathrm{Kg}$, p.o. treatment followed by glimepiride TD ( 0 . $072 \mathrm{mg} / 200$ g, p.o) in respective groups has not shown a significant reduction in blood glucose level.. AQEFCF 100, $200,400 \mathrm{mg} / \mathrm{Kg}$, p.o. treatment followed by glimepiride $2 \mathrm{TD}(0.144 \mathrm{mg} / 200 \mathrm{~g}$, p.o) in respective groups has shown a significant reduction in blood glucose levels at1, 2, 4, 6, $8,10,12,16,24 \mathrm{~h}$ except 10 th $\mathrm{h}$ in $200 \mathrm{mg} / \mathrm{Kg}$ treated group. When compared with single dose of glimepiride 2TD treated group AQEFCF 100, 200, $400 \mathrm{mg} / \mathrm{Kg}$, p.o. treatment followed by glimepiride $1 / 2$ TD $(0.036 \mathrm{mg} / 200 \mathrm{~g}$, p.o) in respective groups has shown a significant reduction in blood glucose levels at 3, 4, 6, 8, 10, 12, 16, $24 \mathrm{~h}$ except $3,12,24 \mathrm{~h}$ in $400 \mathrm{mg} / \mathrm{Kg}$ treated group .

AQEFCF 100, 200, $400 \mathrm{mg} / \mathrm{Kg}$, p.o. treatment followed by glimepiride TD $(0.072 \mathrm{mg} / 200 \mathrm{~g}$, p.o $)$ in respective groups has shown a significant reduction in blood glucose levels at 4, 6, 16h,3,4,6h and 4, $6 \mathrm{~h}$ respectively. AQEFCF 100, 200, $400 \mathrm{mg} / \mathrm{Kg}$, p.o. treatment followed by glimepiride $2 \mathrm{TD}(0.144 \mathrm{mg} / 200 \mathrm{~g}, \mathrm{p} . \mathrm{o})$ in respective groups has shown a significant reduction in blood glucose levels at $8 \mathrm{~h}$ with $100 \mathrm{mg} / \mathrm{Kg}$ dose but not significant with $200 \mathrm{mg} / \mathrm{Kg}$ at any time interval and 4, 6, $10 \mathrm{~h}$ with $400 \mathrm{mg} / \mathrm{Kg}$ dose .

\section{Influence of repeated dose treatment of AQEFCF on} glimepiride (single dose) in diabetic rats ( 8 days study) When compared with single dose of glimepiride $1 / 2$ TD treated group Repeated dose of AQEFCF 100, 200, 400 $\mathrm{mg} / \mathrm{Kg}$, p.o. treatment followed by glimepiride $1 / 2 \mathrm{TD}$ $(0.036 \mathrm{mg} / 200 \mathrm{~g}, \mathrm{p} . \mathrm{o})$ in respective groups has shown a significant reduction in blood glucose levels at 1 and $3 \mathrm{~h}$ with 200 and $400 \mathrm{mg} / \mathrm{Kg}$ doses but has not shown any a significant reduction with $100 \mathrm{mg} / \mathrm{Kg}$ dose. Repeated dose of AQEFCF 100, 200, $400 \mathrm{mg} / \mathrm{Kg}$, p.o. treatment followed by glimepiride TD $(0.072 \mathrm{mg} / 200 \mathrm{~g}, \mathrm{p} . \mathrm{o})$ in respective groups has shown a significant reduction in blood glucose levels at $1,2,4,6,8,10,12,16,24 \mathrm{~h}$ with $200 \mathrm{mg}$ and $400 \mathrm{mg} / \mathrm{Kg}$ doses but not significant at 1,12 and $24 \mathrm{~h}$ with $100 \mathrm{mg} / \mathrm{Kg}$ dose. Repeated dose of AQEF CF 100, 200, $400 \mathrm{mg} / \mathrm{Kg}$, p.o. treatment followed by glimepiride 2TD (0. $144 \mathrm{mg} / 200 \mathrm{~g}$, p.o) in respective groups has shown a significant reduction in blood glucose levels at $1,2,3,4,6,8,10,12,16$ and $24 \mathrm{~h}$ except $24 \mathrm{~h}$ with $400 \mathrm{mg} / \mathrm{Kg}$ dose.

When compared with single dose of glimepiride TD treated group Repeated dose of AQEFCF 100, 200, 400 $\mathrm{mg} / \mathrm{Kg}$, p.o. treatment followed by glimepiride $1 / 2 \mathrm{TD}$ $(0.036 \mathrm{mg} / 200 \mathrm{~g}$, p.o) in respective groups has shown a significant reduction in blood glucose levels at 4, 6 and $8 \mathrm{~h}$ except 6th h with $200 \mathrm{mg}$ and $400 \mathrm{mg} / \mathrm{Kg}$ doses. Repeated dose of AQEFCF 100, 200, $400 \mathrm{mg} / \mathrm{Kg}$, p.o. treatment followed by glimepiride TD $(0.072 \mathrm{mg} / 200 \mathrm{~g}$, p.o $)$ in respective groups has shown a significant reduction in blood glucose levels at 1, 3, 6 and $10 \mathrm{~h}$ except 1 and $3 \mathrm{~h}$ with $100 \mathrm{mg} / \mathrm{Kg}$ and 3 and $6 \mathrm{~h}$ with $200 \mathrm{mg} / \mathrm{Kg}$ doses. (Table No. 41, 42, 43). Repeated dose of AQEFCF 100, $200,400 \mathrm{mg} / \mathrm{Kg}$, p.o. treatment followed by glimepiride $2 \mathrm{TD}(0.144 \mathrm{mg} / 200 \mathrm{~g}, \mathrm{p} . \mathrm{o})$ in respective groups has

Table 3 Influence of single dose treatment of C. frutescens $(400 \mathrm{mg} / \mathrm{kg}$ ) on antidiabetic activity of glimepiride in diabetic rats

\begin{tabular}{|c|c|c|c|c|c|c|}
\hline \multirow[t]{3}{*}{ Time (hr) } & \multicolumn{3}{|c|}{ SERUM GLUCOSE (mg/dL) } & \multicolumn{3}{|l|}{ \% REDUCTION } \\
\hline & \multicolumn{3}{|c|}{$400 \mathrm{mg} \mathrm{C.} \mathrm{frutescens}$} & \multicolumn{3}{|l|}{$400 \mathrm{mg}$ C. frutescens } \\
\hline & $1 / 2$ TD GLIM & 1TD GLIM & 2 TD GLIM & $1 / 2$ TD GLIM & 1TD GLIM & 2 TD GLIM \\
\hline 0 & $322.05 \pm 2.45$ & $316.25 \pm 2.67$ & $305.40 \pm 4.41$ & - & - & - \\
\hline 1 & $295.33 \pm 3.89$ & $286.65 \pm 3.35$ & $266.70 \pm 2.70$ & $8.29 \pm 1.15^{\mathrm{ns}}$ & $9.36 \pm 0.79 \mathrm{~ns}$ & 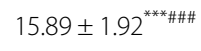 \\
\hline 2 & $272.58 \pm 5.15$ & $258.08 \pm 2.74$ & $241.87 \pm 3.51$ & $15.36 \pm 1.50^{\mathrm{ns}}$ & $18.38 \pm 0.77^{*}$ & $20.65 \pm 2.28^{* * * \# \#}$ \\
\hline 3 & $248.97 \pm 3.85$ & $235.38 \pm 5.46$ & $220.38 \pm 3.34$ & $22.69 \pm 1.07^{\mathrm{ns}}$ & $25.61 \pm 1.16^{\mathrm{ns}}$ & $27.07 \pm 1.88^{* * * \# \#}$ \\
\hline 4 & $224.78 \pm 3.12$ & $199.03 \pm 2.68$ & $180.37 \pm 3.66$ & $30.19 \pm 1.00^{\text {ns\$\$\$ }}$ & $37.05 \pm 0.93^{* * * \$ \$ \$}$ & $40.84 \pm 1.78^{* * * \# \$}$ \\
\hline 6 & $28.63 \pm 2.40$ & $183.98 \pm 2.36$ & $143.42 \pm 3.60$ & $35.22 \pm 0.58^{\text {ns\#\$\$\$ }}$ & $42.12 \pm 0.92^{* * * \$ \$}$ & $52.95 \pm 1.60^{* * * \# \# \# \leftrightarrows}$ \\
\hline 8 & $224.95 \pm 2.95$ & $195.95 \pm 5.09$ & $165.58 \pm 1.04$ & $30.13 \pm 1.10^{\text {ns\#\#\$\$\$ }}$ & $38.01 \pm 1.73^{* * *}$ & $45.71 \pm 1.09^{* * * \# \# \#}$ \\
\hline 10 & $235.97 \pm 3.39$ & $213.27 \pm 3.85$ & $189.88 \pm 1.94$ & $26.67 \pm 1.55^{\mathrm{n} \$ \# \$}$ & $32.52 \pm 1.47^{* *}$ & $39.35 \pm 0.74^{* * * \# \$}$ \\
\hline 12 & $250.0 \pm 5.05$ & $233.62 \pm 3.90$ & $213.70 \pm 3.07$ & $22.31 \pm 2.01^{\mathrm{ns}}$ & $26.10 \pm 1.42^{* * *}$ & $31.72 \pm 1.35^{* * * \#}$ \\
\hline 16 & $270.28 \pm 4.84$ & $252.57 \pm 2.71$ & $239.17 \pm 3.13$ & $16.04 \pm 1.74^{\text {ns\$\$\$ }}$ & $20.12 \pm 0.94^{* * *}$ & $23.61 \pm 1.16^{* * * \# \# \#}$ \\
\hline 24 & $289.28 \pm 2.65$ & $262.98 \pm 4.58$ & $251.95 \pm 4.03$ & $10.18 \pm 0.38^{\mathrm{ns}}$ & $16.37 \pm 1.10^{* * *}$ & $17.37 \pm 2.13^{* * * \# \# \#}$ \\
\hline
\end{tabular}

$\mathrm{n}=6$, ns- non significant, significant at ${ }^{*} P<0.05,{ }^{* *} P<0.01$, ${ }^{* * *} P<0.001$ when compared to control group; ${ }^{\text {ns }} P>0.05,{ }^{\#} P<0.05,{ }^{\# \#} P<0.01$, ${ }^{\# \# \#} P<0.001$ when compared to glimepiride $1 / 2$ TD, $1 T D$ and 2 TD group; when compared to glimepiride TD group 
Table 4 Influence of repeated dose treatment of C. frutescens ( $400 \mathrm{mg} / \mathrm{kg}$ ) on antidiabetic activity of glimepiride in diabetic rats (8th day)

\begin{tabular}{|c|c|c|c|c|c|c|}
\hline \multirow{3}{*}{$\begin{array}{l}\text { Time } \\
\text { (hr) }\end{array}$} & \multicolumn{3}{|c|}{ SERUM GLUCOSE (mg/dL) } & \multicolumn{3}{|l|}{$\%$ REDUCTION } \\
\hline & \multicolumn{3}{|c|}{$400 \mathrm{mg} \mathrm{C.} \mathrm{frutescens}$} & \multicolumn{3}{|c|}{$400 \mathrm{mg} \mathrm{C.} \mathrm{frutescens}$} \\
\hline & $1 / 2$ TD GLIM & 1TD GLIM & 2 TD GLIM & $1 / 2$ TD GLIM & 1TD GLIM & 2 TD GLIM \\
\hline 0 & $307.80 \pm 2.09$ & $293.47 \pm 3.14$ & $298.67 \pm 3.20$ & - & - & - \\
\hline 1 & $272.80 \pm 1.62$ & $257.30 \pm 2.69$ & $249.77 \pm 2.91$ & $11.35 \pm 0.91^{\mathrm{ns} \#}$ & $12.31 \pm 0.69^{* * * \# \# \#}$ & 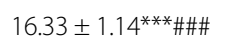 \\
\hline 2 & $255.85 \pm 1.85$ & $235.50 \pm 3.14$ & $226.03 \pm 4.52$ & $16.88 \pm 0.25^{\mathrm{ns}}$ & $19.72 \pm 1.26^{* \# \#}$ & $24.28 \pm 1.69^{* * * \# \# \# \$ \$}$ \\
\hline 3 & $234.20 \pm 2.48$ & $211.52 \pm 4.35$ & $207.52 \pm 2.14$ & $23.91 \pm 0.36^{\mathrm{ns}}$ & $27.94 \pm 1.03^{* * \#}$ & 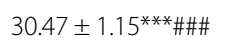 \\
\hline 4 & $202.45 \pm 1.79$ & $181.68 \pm 4.30$ & $173.92 \pm 4.51$ & $34.21 \pm 0.80^{\mathrm{ns}}$ & $38.10 \pm 1.22^{* * *}$ & 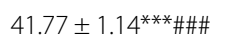 \\
\hline 6 & $192.78 \pm 2.53$ & $157.17 \pm 4.85$ & $139.60 \pm 1.59$ & $37.35 \pm 0.91^{\mathrm{ns} \$ \$ \$}$ & $46.14 \pm 1.56^{* * \# \# \#}$ & 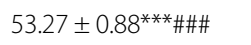 \\
\hline 8 & $209.05 \pm 2.29$ & $173.96 \pm 3.00$ & $155.25 \pm 3.17$ & $32.08 \pm 0.56^{\text {ns\#\$\$\$ }}$ & $40.71 \pm 1.07^{* * \$ \$}$ & 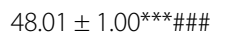 \\
\hline 10 & $222.03 \pm 3.68$ & $195.68 \pm 1.99$ & $183.33 \pm 2.92$ & $27.88 \pm 0.83^{\text {ns\$ }}$ & $33.31 \pm 0.75^{* * * \# \# \#}$ & 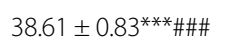 \\
\hline 12 & $237.12 \pm 4.45$ & $211.05 \pm 3.29$ & $202.67 \pm 3.10$ & $22.98 \pm 1.17^{\mathrm{ns}}$ & $28.07 \pm 1.24^{* * *}$ & 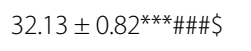 \\
\hline 16 & $255.87 \pm 4.45$ & $228.60 \pm 2.26$ & $232.05 \pm 2.46$ & $16.87 \pm 1.17^{\mathrm{ns}}$ & $22.08 \pm 0.92^{* * \# \# \#}$ & $22.27 \pm 1.00^{* * * \# \#}$ \\
\hline 24 & $269.80 \pm 3.61$ & $245.45 \pm 3.27$ & $243.35 \pm 3.35$ & $12.34 \pm 1.07^{\mathrm{ns}}$ & $16.99 \pm 0.90^{* * \# \# \#}$ & 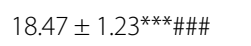 \\
\hline
\end{tabular}

$\mathrm{n}=6$, ns- non significant, significant at ${ }^{*} P<0.05,{ }^{* *} P<0.01,{ }^{* * *} P<0.001$ when compared to control group; ${ }^{\text {ns }} P>0.05,{ }^{*} P<0.05,{ }^{\# \#} P<0.01,{ }^{* \# \#} P<0.001$ when compared to glimepiride $1 / 2$ TD, 1 TD and 2 TD group; when compared to glimepiride TD group; $p<0.05, p<0.01$ and $\$ \$ p<0.001$, ns = not significant when compared with glimepiride 2 TD

shown a significant reduction in blood glucose levels at $1,2,3,4,6,8,10,12,16$ and $24 \mathrm{~h}$. When compared with single dose of glimepiride 2TD treated group Repeated dose of AQEFCF 100, 200, $400 \mathrm{mg} / \mathrm{Kg}$, p.o. treatment followed by glimepiride $1 / 2 \mathrm{TD}(0.036 \mathrm{mg} / 200 \mathrm{~g}$, p.o $)$ in respective groups has shown a significant reduction in blood glucose levels at 1, 3, 4, 6, 8 and $10 \mathrm{~h}$ except 1 and $3 \mathrm{~h}$ with $200 \mathrm{mg}$ and 1,3 and 4 hwith $400 \mathrm{mg}$ doses. Repeated dose of AQEFCF $100,200,400 \mathrm{mg} / \mathrm{Kg}$, p.o. treatment followed by glimepiride TD $(0.072 \mathrm{mg} / 200 \mathrm{~g}$, p.o $)$ in respective groups has shown a significant reduction in blood glucose levels at 6 and $8 \mathrm{~h}$. Repeated dose of AQEFCF $100,200,400 \mathrm{mg} / \mathrm{Kg}$, p.o. treatment followed by glimepiride $2 \mathrm{TD}(0.144 \mathrm{mg} / 200 \mathrm{~g}$, p.o $)$ in respective groups has shown a significant reduction in blood glucose levels at 2 and $12 \mathrm{~h}$ but not observed at $12 \mathrm{~h}$ with 100 and $200 \mathrm{mg} / \mathrm{Kg}$ doses.

\section{Influence of repeated dose treatment of AQEFCF on} glimepiride (repeated dose) in diabetic rats (8 days study) When compared with repeated dose $1 / 2 \mathrm{TD}$ of glimepiride treated group AQEFCF $400 \mathrm{mg} / \mathrm{Kg}$ p.o. repeated dose treatment along with repeated doses of $1 / 2 \mathrm{TD}$, TD and 2TD respectively has not shown a significant reduction in serum glucose levels with $1 / 2 \mathrm{TD}$, significant reduction in glucose levels observed at 2, 3, 6, 8, 10, 12,16 and $24 \mathrm{~h}$ with TD and at all time intervals with 2 TD. When compared with repeated dose TD of glimepiride treated group AQEFCF $400 \mathrm{mg} / \mathrm{Kg}$ p.o. repeated dose treatment along with repeated doses of $1 / 2 \mathrm{TD}$, TD and 2 TD respectively has produced a significant reduction in serum glucose levels at 3 and $8 \mathrm{~h}$ with $1 / 2 \mathrm{TD}$ and $3,6,8$,
10 and $12 \mathrm{~h}$ with $2 \mathrm{TD}$ and no significant reduction in serum glucose levels with TD. When compared with repeated dose 2TD of glimepiride treated group AQEFCF $400 \mathrm{mg} / \mathrm{Kg}$ p.o. repeated dose treatment along with repeated doses of $1 / 2 \mathrm{TD}$, TD and $2 \mathrm{TD}$ respectively has produced a significant reduction in serum glucose levels at $2,3,6,8,10$ and $12 \mathrm{~h}$ with $1 / 2$ TD and 6,8 and $10 \mathrm{~h}$ with TD and no significant reduction in serum glucose levels with $2 \mathrm{TD}$.

Effect of a.vera and Glimepiride on serum insulin levels in diabetic rats by Chemiluminescence method

In one day interaction, all the combination groups shows significant $(P<0.01)$ increase in serum insulin levels when compared to diabetic control group. The maximum increase serum insulin levels observed with glimepiride 2TD after treatment of C. frutescens $(400 \mathrm{mg} / \mathrm{kg}$, p.o.) produced $13.15 \mu \mathrm{u} / \mathrm{m}$. In 8 days interaction study, all the combination groups shows significant $(\mathrm{P}<0.01)$ increase in serum insulin levels when compared to diabetic control group. The maximum increase serum insulin levels observed with repeated treatment of $C$. frutescens $(400 \mathrm{mg} / \mathrm{kg}$, p.o.) daily once for 8 days followed by administration with glimepiride 2 TD $(0.144$ $\mathrm{mg} / 200$ g, p.o.) $30 \mathrm{~min}$ later produced $21.15 \mu \mathrm{u} / \mathrm{ml}$. as shown in Table 5.

\section{Results of pharmacokinetic study}

The obtained pharmacokinetic parameters in this present study were, area under the curve from 0 to last sampling time ( $\mathrm{AUC}_{0-\mathrm{t}}$ ) with a value of $1272(\mathrm{ng} / \mathrm{mL} . \mathrm{hr})$ for glimepiride alone, 1258 (ng/mL.hr) for 1st day 
Table 5 Serum insulin levels on Single and repeated dose administration of $C$. frutescens and glimepiride in diabetic rats (chemi-luminescent immune assay method)

\begin{tabular}{lll}
\hline Groups & $\begin{array}{l}\text { 1st day } \\
\text { Mean } \pm \text { SEM }\end{array}$ & $\begin{array}{l}\text { 8th day } \\
\text { Mean } \pm \text { SEM }\end{array}$ \\
\hline C. frutescens $400 \mathrm{mg} / \mathrm{kg}+1 / 2$ TD GLIM & $9.62 \pm 0.11^{* *}$ & $13.37 \pm 0.78^{* *}$ \\
C. frutescens $400 \mathrm{mg} / \mathrm{kg}+1$ TD GLIM & $10.86 \pm 0.51^{* *}$ & $15.66 \pm 0.3^{* *}$ \\
C. frutescens $400 \mathrm{mg} / \mathrm{kg}+2$ TD GLIM & $13.15 \pm 0.46^{* *}$ & $21.15 \pm 0.73^{* *}$ \\
\hline
\end{tabular}

$\mathrm{n}=6, \mathrm{~ns}=$ not significant, significant at, $P<0.01^{*}, P<0.01^{* *}$

interaction and 1238 (ng/mL.hr) for 15th day interaction. The $\mathrm{T}_{\max }$ for glimepiride alone was $3.58 \mathrm{~h}, 3.58 \mathrm{~h}$ for 1 st day interaction and $3.43 \mathrm{~h}$ for 15 th day interaction. MRM (multiple reaction monitoring) chromatograms from rat plasma samples during pharmacokinetic study was shown in Fig. 4. All other parameters has been summarised in the Table 6 and plasma concentration and time was shown in Fig. 5.

\section{Discussion}

Diabetes, which is metabolic disorder, results may be due to insulin resistance or glucose transport inability from blood to cells [16]. Glimepiride, an oral hypoglycemic drug of the sulfonylurea class indicated to lower the blood glucose in patients with noninsulindependent (Type-2) diabetes mellitus (NIDDM). The primary mechanism of action of glimepiride in lowering blood glucose appears to be dependent on stimulating the release of insulin from functioning islets of langerhans of pancreatic $\beta$-cells. In addition, an extra pancreatic effect can also leads to increased sensitivity of peripheral tissues to insulin [17]. The literature reveals that C.frutescens strengthens the heart and cleanses the lymphatic system and bowel and also stimulates the kidneys. It act as a tonic for the whole body and is used in conditions such as arthritis, rheumatism, fibromyalgia, cramps, cancer, overweight, stomach aches, gas bloating, yellow fever, fever and for gangrene. It is also used with success against angina, alcoholism, asthma, atherosclerosis, bleeding gums, blood clots, bowel diseases bruises, diabetes, diabetic neuropathy, duodenal ulcers, hyper triglyceremia, fatigue, food poisoning, disease conditions due to free radical activity, frost bite, frozen limbs, hardening of the arteries, arrhythmias, haemorrhages, hypertension, inflammation, impotence, indigestion, influenza, itching, joint pain, laryngitis, lumbago, menstrual cramping, motion sickness, mouth sores, multiple sclerosis, muscle aches, inflammation of nerve, neuralgia, night blindness, obesity, pain, peptic ulcer, poor appetite, psoriasis, respiratory disorders, sea sickness, shingles, sores, stomach ulcers, tooth ache, wound, Herpes zoster and shingles. An increasing number of medicinal plants are

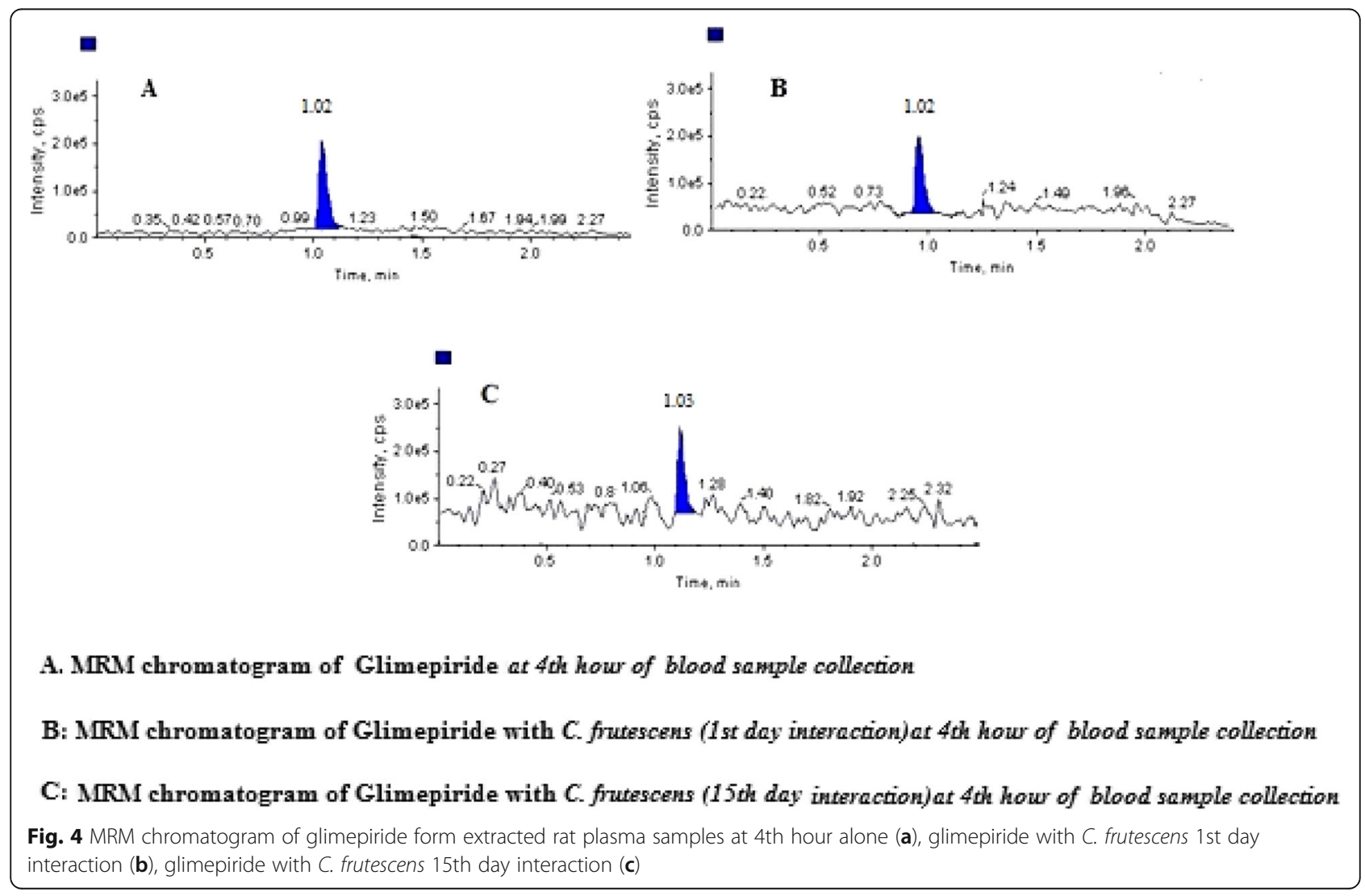


Table. 6 Various pharmacokinetic parameters

\begin{tabular}{llll}
\hline Parameters & Glimepiride & Glipmepiride + C. frutescens (1st day interaction) & Glipmepiride + C. frutescens (15th day interaction) \\
\hline$C_{\max } \mathrm{ng} / \mathrm{mL}$ & $71.23 \pm 23.22$ & $70.98 \pm 22.34$ & $71.03 \pm 36.33$ \\
$\mathrm{~T}_{\max }$ hours & $3.6 \pm 1.27$ & $3.58 \pm 0.98$ & $3.43 \pm 1.11$ \\
$\mathrm{~T}_{1 / 2} \mathrm{~h}$ & $6.93 \pm 2.10$ & $6.81 \pm 1.29$ & $6.78 \pm 2.32$ \\
$\mathrm{AUC}_{0-\mathrm{t}}(\mathrm{ng} / \mathrm{mL} / \mathrm{hr})$ & $1272 \pm 34.45$ & $1258 \pm 46.79$ & $1238 \pm 41.85$ \\
$\mathrm{AUC}_{0-\infty}(\mathrm{ng} / \mathrm{mL} / \mathrm{hr})$ & $162.62 \pm 44.56$ & $160.12 \pm 21.65$ & $161.32 \pm 43.67$ \\
\hline
\end{tabular}

being used to treat diabetes and its related conditions. Many of these plants have been used ethnopharmacologically in traditional medicine as antidiabetics, particularly for T2DM. Te co-administration of antidiabetic herbs and pharmaceutical agents may result in enhanced efects (which may be desirable clinically), decreased pharmacological efects, or adverse drug events, such hypoglycemia. Combination with ginger extract reduces blood glucose level greater than Glimiperide alone. The present study was undertaken to evaluate any possible food-drug interaction between C.frutescens and glimepiride with single and repeated dose treatment of C.frutescens on hypoglycemic and antidiabetic activity of glimepiride in normal and diabetic rats. When the aqueous extract of C.frutescens (AQEFCF) was administered orally to different groups of mice at different dose levels, it was found that even up to the dose level of $2000 \mathrm{mg} / \mathrm{Kg}$ body weight, the extract showed no effect either on behavioral symptoms or mortality during the observation period of $48 \mathrm{~h}$ (short term toxicity) and no mortality observed up to 14 days of experimental study (long term toxicity). $0.1 \mathrm{~N} \mathrm{NaOH}$ used as vehicle in control has not shown any reduction in the serum glucose levels in both single and in repeated treatment studies. Based on the results it can concluded that, $1 / 2 \mathrm{TD}$, TD and 2 TD glimepiride doses exhibited a significant and dose dependent antidiabetic activity. Similarly 100, 200, $400 \mathrm{mg} / \mathrm{kg}$ doses of AQEFCF also exhibited a significant and dose dependent reduction in serum glucose levels in diabetic rats. In one day interaction study 100, 200, 400 $\mathrm{mg} / \mathrm{kg}$ doses of AQEFCF and $1 / 2 \mathrm{TD}$, TD and 2 TD glimepiride was increased the antidiabetic activity of $1 \%$, $3 \%$ and $5 \%$ respectively. In 8 day interaction study /repeated dose treatment $100,200 \mathrm{mg} / \mathrm{kg}$ doses of AQEFCF and single dose treatment of $\frac{1}{2} \mathrm{TD}$, TD and 2 TD glimepiride was increased the antidiabetic activity of $2-4 \%, 1-$

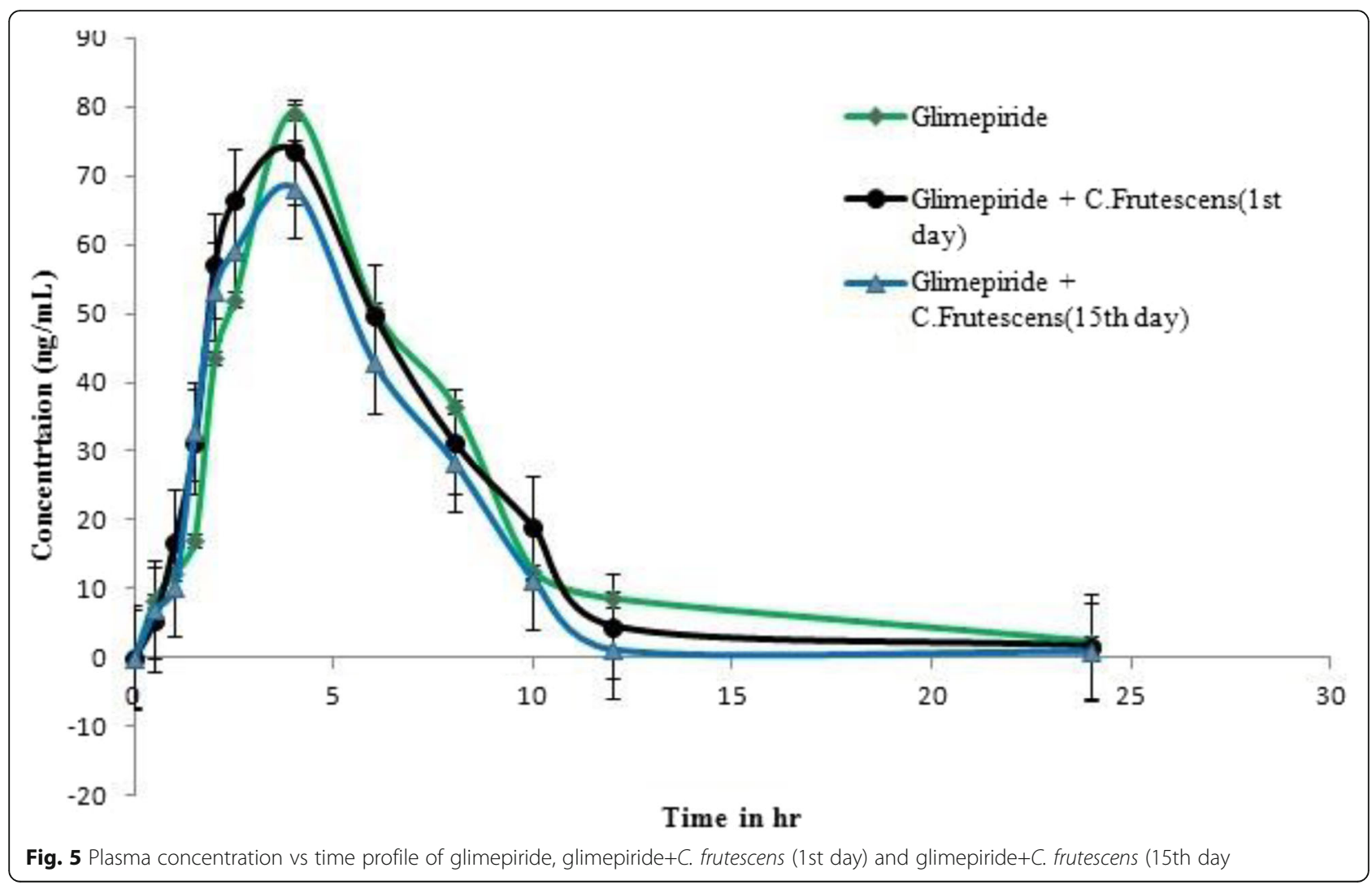


$7 \%$ and $3-5 \%$ respectively. Whereas $400 \mathrm{mg} / \mathrm{kg}$ of AQEF CF followed by single dose treatment of $1 / 2 \mathrm{TD}$, TD and 2 TD glimepiride was increased the antidiabetic activity of $3 \%, 1 \%$ and $4 \%$ respectively. In the present study results revealed that a significant increase serum insulin levels was observed in diabetic rats when treated with combination of C.frutescens and glimepiride when compared to single drug/herb treated groups. It is possible that C.frutescens may initiate cell proliferation, since it has been reported that pancreatic endocrine cells have the potential to proliferate after induction of diabetes with STZ (11). It was reported that glimepiride has effect on the $\beta$-cells and increase the insulin secretion (12). Therefore, the combination of C.frutescens $(400 \mathrm{mg} / \mathrm{kg})$ with glimepiride 2 TD $(0.144 \mathrm{mg} / 200$ g, p.o. $)$ caused significant increase in serum insulin levels than individual treatment with glimepiride confirmed that extra increase in insulin levels are due to C.frutescens only. In the present study we were investigated the pharmacokinetic interaction of Capsicum frutescens L. and Glimepiride at therapeutic doses in healthy rats. There was no significant rise in plasma Glimiperide levels and pharmacokinetic parameters. In the 1st day and 15th day interaction study all the pharmacokinetic parameters values of only Glimiperide and Glimiperide with Capsicum frutescens L was found almost similar. Therefore it was stated that there was there is no pharmacokinetic interaction between Capsicum frutescens L. and Glimepiride.

\section{Conclusion}

Herb-drug interaction is an important issue affecting the efficacy and safety of therapeutic treatments. In the present study, no severe hypoglycemia or convulsions are noted with any of the experimental animals i.e., diabetic rats during study. Hence the study clearly confirmed that no significant food-drug interaction occurred between aqueous extract of C.frutescens and glimepiride either in combination of single doses or in combination of repeated doses because there was no influence on the pancreatic and extra pancreatic (cellular utilization of glucose) mechanisms that influence blood glucose.

\section{Acknowledgements}

The authors are Thankful to Management of V.L.College of Pharmacy for providing necessary facilities to conduct this research work.

\section{Authors' contributions \\ Dr. MA raja, Dr. P. Mondal designed the entire project work and carried acute toxicity study and herb- drug, interaction study in normal rats. Dr. MT, $\mathrm{Mr}$. KV induced the diabetes to the animal and carried out herb- drug, interaction study in diabetic rats. Dr. Mondal and Mr. K Venu and P. Kiran has designed and carried out pharmacokinetic study. All the authors revised and approved the final manuscript and the research work was performed in collaboration between all the authors.}

\section{Funding}

This research did not received any specific grant from any funding agencies.
Availability of data and materials

All data and material is available upon request.

\section{Ethics approval and consent to participate}

It is approved by the IAEC (Institutional animal ethical committee) of VL college of Pharmacy. Reference number of the ethics committee is 557/08/C/ CPCSEA.

Consent for publication

Non Applicable.

\section{Competing interests}

The authors declare that they have no competing interest.

\section{Author details}

'Department of Biomedical Engineering, Dr. N.G.P Institute of technology, Coimbatore, Tamilnadu 641048, India. ${ }^{2}$ Vaageswari Institute of

Pharmaceutical sciences, LMD Colony, Karimnagar 505481, India. ${ }^{3}$ Vaageswari College of Pharmacy, LMD Colony, Karimnagar 505481, India. ${ }^{4}$ Balaji Institute of Pharmaceutical Sciences, Narsampet, Warangal 506132, India.

Received: 18 October 2019 Accepted: 3 July 2020

Published online: 12 July 2020

\section{References}

1. Prasad KP, Tharangani PG, Samaranayake CN. Recurrent relapses of depression in a patient established on sertraline after taking herbal medicinal mixtures-a herb-drug interaction. J Psychopharmacol. 2009;23: 216-9.

2. Chan $\mathrm{K}$. Some aspects of toxic contaminants in herbal medicines. Chemosphere. 2003;52:1361-71.

3. Gohil K, Patel JA. Herb-drug interactions: a review and study based on assessment of clinical case reports in literature. Indian J Pharmacol. 2007;39: 129-39.

4. Genser D. Food and drug interaction: consequences for the nutrition/health status. Ann Nutr Metab. 2008:52(suppl 1):29-32.

5. Bushra R, Aslam N, Khan AY. Food-drug interactions. Oman Med J. 2011;26: 77-83.

6. Leibovitch ER, Deamer RL, Sanderson LA. Food-drug interactions: careful drug selection and patient counselling can reduce the risk in older patients. Geriatrics. 2004:59:19-22 32-3.

7. Becic F, Kapic E, Becic E. Glimepiride--an oral antidiabetic agent. Med Arh. 2003:57(2):125-7.

8. Mohammed A, Koorbanally N, Md SI. Anti-diabetic effect of Capsicum annuum $\mathrm{L}$. fruit acetone fraction in a type 2 diabetes model of rats. Acta poloniae pharmaceutica. 2017;74(6):1767-79.

9. Kola V, Mondal P, Thimmaraju MK, Mondal S, Rao NV. Antiarthritic potential of aqueous and ethanolic fruit extracts of "Momordica charantia"using different screening models. Pharcog Res. 2018;10(3):258-64.

10. Singh S, Kesari AN, Gupta R, Jaiswal D, Watal G. Assessment of antidiabetic potential of Cynodon dactylonextract in streptozotocin diabetic rats. J Ethnopharmacol. 2007;1(2):174-9.

11. Ghosh MN. Fundamentals of Experimental pharmacology, $3^{\text {rd }}$ edn. Chicago: Hilton and Company; 2005. p. 192.

12. Egede $L E$, Ye $X$, Zheng $D$, Silverstein MD. The prevalence and pattern of complementary and alternative medicine use in individuals with diabetes. Diabetes Care. 2002;25:324-9

13. Carslake HB, Pinchbeck GL, McGowan CM. Evaluation of a Chemiluminescent immunoassay for measurement of equine insulin. J Vet Intern Med. 2017;31:568-74.

14. Alshammari TM, Al-Hassan AA, Hadda TB, Aljofan M. Comparison of different serum sample extraction methods and their suitability for mass spectrometry analysis. Soudi Pharm J. 2015;23:689-97.

15. Kim H, Chang KY, Park CH, Jang MS, Lee J, Lee HJ. Determination of glimepiride in human plasma by LC-MS-MS and comparison of sample preparation methods for glimepiride. Chromatographia. 2004;60:93-8.

16. Ikumi Y, Kida T, Sakuma S, Yamashita S, Akashi M. Polymer-phloridzin conjugates as an anti-diabetic drug that inhibits glucose absorption through the Nat/glucose cotransporter (SGLT1) in the small intestine. Cont Rel. 2008;125:42-9. 
17. Chaiyasit K, Khovidhunkit W, Wittayalertpanya S. Pharmacokinetic and the effect of capsaicin in Capsicum frutescens on decreasing plasma glucose level. J Med Assoc Thail. 2009;92(1):108-13.

\section{Publisher's Note}

Springer Nature remains neutral with regard to jurisdictional claims in published maps and institutional affiliations.

Submit your manuscript to a SpringerOpen ${ }^{\mathcal{O}}$ journal and benefit from:

- Convenient online submission

- Rigorous peer review

- Open access: articles freely available online

- High visibility within the field

- Retaining the copyright to your article

Submit your next manuscript at $\boldsymbol{\wedge}$ springeropen.com 